\title{
ANALYSIS OF MAJOR, MINOR AND TRACE ELEMENTS IN SURFACE SEDIMENTS BY X-RAY FLUORESCENCE SPECTROMETRY FOR ASSESSMENT OF POSSIBLE CONTAMINATION OF BOKA KOTORSKA BAY, MONTENEGRO
}

\author{
Bojan Tanaskovski ${ }^{1}$, Marija Petrović ${ }^{2}$, Zoran Kljajić ${ }^{3}$, Sandro Degetto ${ }^{4}$, \\ Slavka Stanković ${ }^{1 *}$ \\ ${ }^{1}$ Faculty of Technology and Metallurgy, Department of Analytical Chemistry, \\ University of Belgrade, 4 Karnegijeva St., 11000 Belgrade, Serbia \\ ${ }^{2}$ Institute for Technology of Nuclear and Other Mineral Raw Materials, \\ 86 Franchet d'Esperey St., 11000 Belgrade, Serbia \\ ${ }^{3}$ Institute of Marine Biology, University of Podgorica, 85330 Kotor, Dobrota bb, Montenegro \\ ${ }^{4}$ ICIS-CNR, Environmental Laboratory, 35127 Padua, Italy \\ slavka@tmf.bg.as.rs
}

Boka Kotorska Bay is on the UNESCO's World Heritage List. There are no published papers related to the surface sediment pollution of the Bay. For the first time, elements were measured in surface sediments at nine locations in the Bay by the energy dispersive X-ray fluorescence spectrometry (ED$\mathrm{XRF}$ ) technique. $\mathrm{Si}, \mathrm{Fe}, \mathrm{Ca}, \mathrm{K}, \mathrm{Ti}, \mathrm{Mn}, \mathrm{P}, \mathrm{Ba}, \mathrm{Cr}, \mathrm{Sr}, \mathrm{Zn}, \mathrm{Rb}, \mathrm{Ni}, \mathrm{Cu}, \mathrm{Pb}, \mathrm{As}, \mathrm{Sn}, \mathrm{Sb}, \mathrm{Hg}$ and $\mathrm{Cd}$ were quantified in the surface sediments. Sediments were classified as non-polluted or polluted by counting the enrichment factor $(E F)$, metal loading index $(M L I)$ and geo-accumulation index $\left(I_{g e o}\right)$ based on the elemental background level of the analyzed elements in the literature, or by the Sediment Quality Guidelines (SQGs) of USEPA (United States Environmental Protection Agency). Based on USEPA's SQGs, the surface sediment in the entire Bay can be classified as heavily polluted by As and $\mathrm{Cr}$, and non-polluted by $\mathrm{Cd}$ and $\mathrm{Hg}$, and, related to the sites, the surface sediment at the Tivat-Arsenal site was heavily polluted and at the Orahovac site was not polluted at all. The PLI (pollution load index) values for the locations of Tivat-Arsenal and Orahovac are in agreement with the conclusion based on USEPA's SQGs. The results in this paper will establish an initial view of sediment pollution and the state of the Bay's environment.

Keywords: multi-element analysis; marine sediment; pollution index; geochemical analysis

\section{АНАЛИЗА НА МАКРО- И МИКРОЕЛЕМЕНТИ ВО ПОВРШИНСКИТЕ СЕДИМЕНТИ СО РЕНДГЕНСКА ФЛУОРЕСЦЕНТНА СПЕКТРОМЕТРИЈА ЗА УТВРДУВАЊЕ НА МОЖНАТА ЗАГАДЕНОСТ НА ЗАЛИВОТ БОКА КОТОРСКА, ЦРНА ГОРА}

Заливот Бока Которска е на листата на светското наследство на УНЕСКО. Не постојат објавени трудови поврзани со површинското загадување на заливот. За прв пат на девет локации во заливот елементите во површинските седименти се измерени со техниката на енергетска дисперзиона рендгенска флуоресцентна спектрометрија. Во површинските наслаги беа измерени $\mathrm{Si}, \mathrm{Fe}, \mathrm{Ca}, \mathrm{K}, \mathrm{Ti}, \mathrm{Mn}, \mathrm{P}, \mathrm{Ba}, \mathrm{Cr}, \mathrm{Sr}, \mathrm{Zn}, \mathrm{Rb}, \mathrm{Ni}, \mathrm{Cu}, \mathrm{Pb}, \mathrm{As}, \mathrm{Sn}, \mathrm{Sb}, \mathrm{Hg}$ и Cd. Наслагите беа класифицирани како незагадени или загадени со пресметување на факторот на збогатување на наслагите (седиментите) со метали $(E F)$, индексот на таложење на метали (MLI) и геоакумулационен индекс $\left(I_{g e o}\right)$ базиран на литературните податоци за елементарно ниво на анализираните елементи, односно врз основа на Упатството за квалитетот на седиментот $(S Q G)$ на USEPA. Врз основа на SQGs на USEPA, површинскиот седимент во заливот како целина може да се класифицира како силно загаден со $\mathrm{As}$ и $\mathrm{Cr}$ и како незагаден со $\mathrm{Cd}$ и $\mathrm{Hg}$, а во однос на одделни локации површинскиот седимент во Тиват-Арсенал беше многу загаден, а во Ораховац воошто не беше загаден. Вредностите PLI за локациите Тиват-Арсенал и Ораховац се во согласност со 
заклучокот базиран на $S Q G$ s на USEPA. Резултатите од овој труд ќе ја создадат почетната претстава за загадувањето на седиментите и за состојбата на животната средина на заливот.

Клучни зборови: мултиелементарна анализа; морски наслаги (седименти); индекс на загадување; геохемиска анализа

\section{INTRODUCTION}

The Boka Kotorska Bay is situated in the southeastern Adriatic Sea (Mediterranean Sea), along the Montenegro coastline. As one of the most beautiful bays in the world, it is on UNESCO's World Heritage List. The bay comprises drowned valleys flooded by the rising sea. Sometimes called Europe's southernmost fjord [1], it is in fact a ria of the disintegrated Bokelj River which used to run from the high Mount Orjen. The Boka Kotorska Bay is a semi-enclosed bay. The entrance is 2.95 $\mathrm{km}$. It is hypothesized that the Boka Kotorska Bay, having a coastline $105.7 \mathrm{~km}$ long, covering an area of $87.3 \mathrm{~km}^{2}$, containing a volume of $2.4 \times 10^{6} \mathrm{~km}^{3}$ of water and with a maximum depth of $60 \mathrm{~m}$ in small Kotor Bay, was formed by fluvial erosion [2] with a complex morphological structure, consisting of four embayments naturally divided into smaller bays: the Herceg Novi, Tivat, Risan-Morinj and Kotor Bays. The bottom of the bay, whose mean depth varies from 30 to $40 \mathrm{~m}$, has the form of a plateau filled with deposits [3]. Relief characteristics stimulated the development of urban agglomerations along the bay coast; especially suitable farming zones have been placed in the very neighborhood of Kotor, Risan, Herceg Novi, and recently Tivat [3].

They are connected and interact with the sea through narrow straits and the bay can be considered one of the main freshwater inputs into the southern Adriatic Sea. The innermost Kotor and Morinj bays, generally exchange little water with the sea and they have high values of residence times and these bays are different from the outermost areas. The Kotor and Morinj bays have the highest fresh water springs and river discharges, while the rest of the Boka Kotorska Bay seems to be mostly affected by the freshwater influence from precipitation and karstic river discharges [3]. On average, the Boka Kotorska Bay situation presents a surface outflow and a bottom inflow of water [1]. The specific hydrogeology of the bay influences the surface sediment composition in the Boka Kotorska Bay.

The investigation of sediments is more marked along the Italian coast than along the eastern Adriatic coast [4]. Although the studies of ele- ment contents in the Adriatic sediments date back more than 30 years, the available data and publications are mostly limited to selected coastal areas of the eastern Adriatic [5] and some data sets of major, minor and trace elements covering the southeastern Adriatic [6]. Investigations of the surface sediment in the southeastern Adriatic have intensified in the Albanian coastal area [4, 7, 8] and some hint of the work in relation to the concentrations of the elements in surface sediments in the Montenegrin coast $[9,10]$.

Sediments act as sinks and sources of contaminants in aquatic systems because of their variable physical and chemical properties [11]. Analysis of the pollutants in sediments is vital as they are adsorbed by material in suspension and by finegrained particles. Pekey (2006) [11] demonstrated that heavy metals tend to be trapped in aquatic environments and accumulate in sediments. According to some authors [12] environmental quality indexes are a powerful tool for determining the metal contaminants in sediments and can be classified into three types: (i) contamination indexes which compare the contaminants with clean or polluted stations measured elsewhere; (ii) background enrichment indexes which compare the results for the contaminants with the baseline or background levels and (iii) ecological risk indexes which compare the results for the contaminants with Sediment Quality Guidelines (SQGs).

No papers were found on the heavy metals distribution in the surface sediments of Montenegro. This report presents the investigation of 20 elements ( $\mathrm{Si}, \mathrm{Fe}, \mathrm{Ca}, \mathrm{K}, \mathrm{Ti}, \mathrm{Mn}, \mathrm{P}, \mathrm{Ba}, \mathrm{Cr}, \mathrm{Sr}, \mathrm{Zn}$, $\mathrm{Rb}, \mathrm{Ni}, \mathrm{Cu}, \mathrm{Pb}, \mathrm{As}, \mathrm{Sn}, \mathrm{Sb}, \mathrm{Hg}$ and $\mathrm{Cd}$ ) measured in the surface sediments at nine locations in Boka Kotorska Bay by energy dispersive X-ray fluorescence spectrometry (ED-XRF). The subject of this research involves the surface sediments collected at locations with poor open seawater mixing (Kotor and Risan-Morinj bays), with a weakened sea current and waves (Tivat Bay) and impacted with sea current and waves (Herceg Novi Bay). Due to the increasing developments in the Boka Kotorska Bay, the study aims were: (1) to assess the major and minor element concentrations in the surface bay sediment; (2) to compare the metal concentrations with the $S Q G$ s promulgated by the United 
States Environmental Protection Agency (USEPA) [13]; and (3) to compare the pollution indexes to describe the bay's sediment quality.

\section{EXPERIMENTAL}

Samples of surface sediments were collected in June 2007 at the nine selected locations in the Boka Kotorska Bay: Krtole, Tivat-Airport, TivatArsenal, Kotor, Orahovac, Risan, Morinj, Bijela Port and Herceg Novi, as indicated in Figure 1, situated in the proximity of different hydrological and human impacts. Tivat, Kotor, and Herceg Novi represent the most populated cities with the highest residential populations: 12000, 19000 and 26000, respectively. The samples were collected from boats anchored in front of the sites usually from depths of 17 to $20 \mathrm{~m}$, except for the Tivat-Airport and Herceg Novi sites, where the depths were 12 and $22 \mathrm{~m}$, respectively. The core depth was from 22-70 cm, depending on the location.

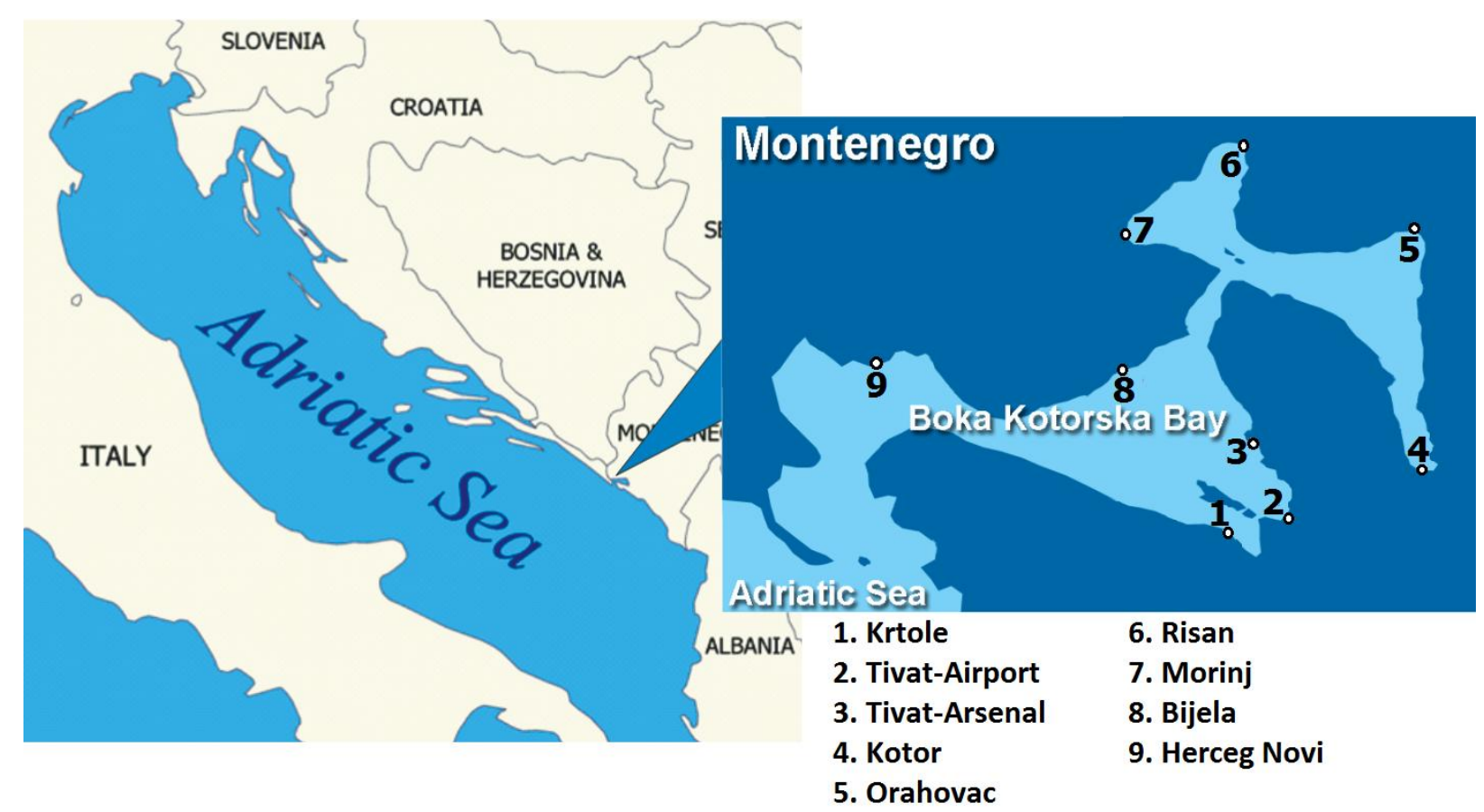

Fig. 1. Sampling stations in Boka Kotorska Bay, Montenegro

At all locations the sediment sampling was undertaken by a grab sampler from the boat. The analysis of the major, minor and trace elements in the sediment samples was measured on the fraction $<63 \mu \mathrm{m}$. Concentrations of 20 elements ( $\mathrm{Si}, \mathrm{Ca}, \mathrm{K}$, $\mathrm{Fe}, \mathrm{Ti}, \mathrm{Mn}, \mathrm{P}, \mathrm{Ba}, \mathrm{Cr}, \mathrm{Sr}, \mathrm{Zn}, \mathrm{Rb}, \mathrm{Ni}, \mathrm{Cu}, \mathrm{Pb}, \mathrm{As}$, $\mathrm{Sn}, \mathrm{Sb}, \mathrm{Hg}$ and $\mathrm{Cd}$ ) were measured by the EDXRF method. ED-XRF is a nondestructive method which requires little or no sample preparation and gives reliable results in a reasonable amount of time (a few minutes depending on the sample type). Measurements were performed using a PANalytical MiniPal 4 ED-XRF spectrometer, equipped with a $30 \mathrm{kV} \mathrm{Rh}$ anode tube (maximum power: 9 $\mathrm{W}$; window: $75 \mu \mathrm{m} \mathrm{Be}$; maximum high voltage: 30 $\mathrm{kV}$; maximum current: $750 \mu \mathrm{A}$; cooling medium: air), a high-resolution silicon drift detector (SDD), a spinner and a 12-position removable sample changer. The resolution of the SDD is $145 \mathrm{eV}$. Spectral data were analyzed by MiniPal/MiniMate software version 3.0.-63(2.64) (PANalytical, Almelo, The Netherlands).

The ED-XRF system for sediment analysis was calibrated on the basis of four LGC (USA) standard reference materials measurements: NIM GBW 07428, NIM GBW 07427, NIM GBW 07430 and NIM GBW 07419. In order to reduce the background and to improve the element of interest intensity, four filters were used during the elements analysis between the X-ray source and samples to filter out unwanted X-ray peaks: $\mathrm{Al}$ thin filter - thickness $50 \mu \mathrm{m}$; Al filter - thickness 200 $\mu \mathrm{m}, \mathrm{Ag}$ filter - thickness $200 \mu \mathrm{m}$ and Mo filter thickness $100 \mu \mathrm{m}$. Optimum measurement parameters for each group of elements are presented in Table 1. 
T a ble 1

Measured conditions for elements determination by ED-XRF

\begin{tabular}{|c|c|c|c|c|c|c|c|c|}
\hline Elements & Line name & $\begin{array}{c}\text { Electric } \\
\text { potential } \\
\text { difference, } \\
\mathrm{V}\end{array}$ & $\begin{array}{c}\text { Electric } \\
\text { current, } \\
\mu \mathrm{A}\end{array}$ & $\begin{array}{l}\text { Tube } \\
\text { filter } \\
\text { name }\end{array}$ & $\begin{array}{c}\text { Thickness } \\
\text { of filter, } \\
\mu \mathrm{m}\end{array}$ & $\begin{array}{c}\text { Mass } \\
\text { density, } \\
\mathrm{g} \mathrm{cm}^{-3}\end{array}$ & Medium & $\begin{array}{c}\text { Measuring } \\
\text { time, } \\
\mathrm{s}\end{array}$ \\
\hline $\mathrm{Ba}, \mathrm{Ti}, \mathrm{P}$ & $\mathrm{L} \alpha, \mathrm{K} \alpha, \mathrm{K} \alpha$ & 12000 & 750 & $\mathrm{Al}$ thin & 50 & 2.7 & Air & 100 \\
\hline $\begin{array}{l}\text { As, } \mathrm{Hg}, \mathrm{Sr} \\
\mathrm{Cd}, \mathrm{Sn}, \mathrm{Sb}\end{array}$ & $\begin{array}{l}\mathrm{K} \alpha, \mathrm{L} \alpha, \mathrm{K} \alpha \\
\mathrm{L} \alpha, \mathrm{L} \alpha, \mathrm{L} \alpha\end{array}$ & 30000 & 300 & $\mathrm{Ag}$ & 100 & 10.5 & Air & 100 \\
\hline $\mathrm{Cr}$ & $\mathrm{K} \alpha$ & 20000 & 300 & $\mathrm{Al}$ & 200 & 2.7 & Air & 200 \\
\hline $\mathrm{Ca}, \mathrm{Fe}, \mathrm{K}$ & $\mathrm{K} \alpha, \mathrm{K} \alpha, \mathrm{K} \alpha$ & 13000 & 650 & $\mathrm{Al}$ thin & 50 & 2.7 & Air & 400 \\
\hline $\mathrm{Rb}, \mathrm{Zn}$ & $\mathrm{K} \alpha, \mathrm{K} \alpha$ & 30000 & 200 & $\mathrm{Al}$ & 200 & 2.7 & Air & 400 \\
\hline $\mathrm{Cu}, \mathrm{Mn}, \mathrm{Ni}$ & $\mathrm{K} \alpha, \mathrm{K} \alpha, \mathrm{K} \alpha$ & 20000 & 405 & Mo & 100 & 10.22 & Air & 200 \\
\hline $\mathrm{Pb}$ & $\mathrm{L} \alpha$ & 30000 & 270 & Mo & 100 & 10.22 & Air & 200 \\
\hline $\mathrm{Si}$ & $\mathrm{K} \alpha$ & 8000 & 750 & none & 0 & 0 & Air & 500 \\
\hline
\end{tabular}

In order to test the precision and accuracy of the method, the measurements were checked primarily by measuring LGC standard samples (NIM
GBW 07428 and NIM GBW 07402), Table 2, under the same conditions as standard referent material samples.

\section{Table 2}

Analysis of certified reference materials: certified values and found values (mean $\pm S . D ., \mathrm{mg} \mathrm{kg}^{-1} \mathrm{dw}$ )

\begin{tabular}{|c|c|c|c|c|c|c|c|c|c|}
\hline \multirow{2}{*}{ Elements } & \multicolumn{2}{|c|}{ GBW 07428} & \multicolumn{2}{|c|}{ GBW 07402} & \multirow{2}{*}{ Elements } & \multicolumn{2}{|c|}{ GBW 07428} & \multicolumn{2}{|c|}{ GBW 07402} \\
\hline & Certified & Found & Certified & Found & & Certified & Found & Certified & Found \\
\hline $\mathrm{Si}$ & $\begin{array}{c}301473.0 \\
\pm 1869.6\end{array}$ & $\begin{array}{l}295957 \\
\pm 467.4\end{array}$ & $\begin{array}{c}342838 \\
\pm 1262\end{array}$ & $\begin{array}{l}357420 \\
\pm 467.4\end{array}$ & $\mathrm{Cr}$ & $\begin{array}{c}70.0 \\
\pm 3.0\end{array}$ & $\begin{array}{c}68.7 \\
\pm 2.14\end{array}$ & $\begin{array}{c}47 \\
\pm 6.0\end{array}$ & $\begin{array}{c}48.8 \\
\pm 0.07\end{array}$ \\
\hline $\mathrm{Ca}$ & $\begin{array}{r}17510 \\
\pm 357.3\end{array}$ & $\begin{array}{l}18081 \\
\pm 56.0\end{array}$ & $\begin{array}{c}16867 \\
\pm 500.0\end{array}$ & $\begin{array}{l}14222 \\
\pm 33.8\end{array}$ & $\mathrm{Ni}$ & $\begin{array}{c}33.0 \\
\pm 2.0\end{array}$ & $\begin{array}{c}30.0 \\
\pm 0.13\end{array}$ & $\begin{array}{l}19.4 \\
\pm 1.9\end{array}$ & $\begin{array}{c}23.8 \\
\pm 0.48\end{array}$ \\
\hline $\mathrm{Sr}$ & $\begin{array}{l}152.0 \\
\pm 5.0\end{array}$ & $\begin{array}{l}149.0 \\
\pm 1.0\end{array}$ & $\begin{array}{l}187.0 \\
\pm 14.0\end{array}$ & $\begin{array}{l}194.7 \\
\pm 1.5\end{array}$ & $\mathrm{Zn}$ & $\begin{array}{c}96.0 \\
\pm 3.0\end{array}$ & $\begin{array}{r}91.6 \\
\pm 2.67\end{array}$ & $\begin{array}{c}42 \\
\pm 5.0\end{array}$ & $\begin{array}{c}42.0 \\
\pm 1.93\end{array}$ \\
\hline $\mathrm{Ba}$ & $\begin{array}{l}608.0 \\
\pm 13.0\end{array}$ & $\begin{array}{c}573.1 \\
\pm 9.1\end{array}$ & $\begin{array}{l}930.0 \\
\pm 81.0\end{array}$ & $\begin{array}{l}962.7 \\
\pm 24.4\end{array}$ & $\mathrm{Cu}$ & $\begin{array}{c}27.4 \\
\pm 1.1\end{array}$ & $\begin{array}{c}18.4 \\
\pm 0.60\end{array}$ & $\begin{array}{l}16.3 \\
\pm 1.4\end{array}$ & $\begin{array}{c}22.2 \\
\pm 0.23\end{array}$ \\
\hline K & $\begin{array}{r}20420 \\
\pm 581.0\end{array}$ & $\begin{array}{r}20835 \\
\pm 137.3\end{array}$ & $\begin{array}{c}21085 \\
\pm 581.1\end{array}$ & $\begin{array}{r}19424 \\
\pm 496.9\end{array}$ & $\mathrm{~Pb}$ & $\begin{array}{c}31.0 \\
\pm 1.0\end{array}$ & $\begin{array}{c}28.1 \\
\pm 1.22\end{array}$ & $\begin{array}{c}20 \\
\pm 4.0\end{array}$ & $\begin{array}{c}19.1 \\
\pm 1.51\end{array}$ \\
\hline $\mathrm{P}$ & $\begin{array}{l}730.0 \\
\pm 28.0\end{array}$ & $\begin{array}{c}675.7 \\
\pm 9.2\end{array}$ & $\begin{array}{l}446.0 \\
\pm 38.0\end{array}$ & $\begin{array}{c}432.3 \\
\pm 7.6\end{array}$ & As & $\begin{array}{c}6.5 \\
\pm 1.3\end{array}$ & $\begin{array}{l}8.7 \\
\pm 1.43\end{array}$ & $\begin{array}{l}13.7 \\
\pm 1.8\end{array}$ & $\begin{array}{c}13.1 \\
\pm 1.25\end{array}$ \\
\hline $\mathrm{Fe}$ & $\begin{array}{c}37208 \\
\pm 419.6\end{array}$ & $\begin{array}{l}37487 \\
\pm 96.5\end{array}$ & $\begin{array}{c}24619 \\
\pm 699.4\end{array}$ & $\begin{array}{r}22450 \\
\pm 656.7\end{array}$ & $\mathrm{Sn}$ & $\begin{array}{c}3.1 \\
\pm 0.3\end{array}$ & $\begin{array}{c}3.8 \\
\pm 0.03\end{array}$ & $\begin{array}{c}3.0 \\
\pm 0.4\end{array}$ & $\begin{array}{c}3.26 \\
\pm 0.03\end{array}$ \\
\hline $\mathrm{Ti}$ & $\begin{array}{c}4060 \\
\pm 130.0\end{array}$ & $\begin{array}{c}4157.2 \\
\pm 31.3\end{array}$ & $\begin{array}{c}2710 \\
\pm 120.0\end{array}$ & $\begin{array}{c}2419.3 \\
\pm 88.0\end{array}$ & $\mathrm{Sb}$ & $\begin{array}{c}0.73 \\
\pm 0.08\end{array}$ & $\begin{array}{c}0.72 \\
\pm 0.026\end{array}$ & $\begin{array}{c}1.3 \\
\pm 0.3\end{array}$ & $\begin{array}{c}1.28 \\
\pm 0.12\end{array}$ \\
\hline $\mathrm{Rb}$ & $\begin{array}{l}108.0 \\
\pm 4.0\end{array}$ & $83.8 \pm 7.3$ & $\begin{array}{l}88.0 \\
\pm 5.0\end{array}$ & $\begin{array}{l}69.7 \\
\pm 5.5\end{array}$ & $\mathrm{Cd}$ & $\begin{array}{c}0.20 \\
\pm 0.02\end{array}$ & $\begin{array}{c}0.21 \\
\pm 0.015\end{array}$ & $\begin{array}{l}0.071 \\
\pm 0.02\end{array}$ & $\begin{array}{c}0.07 \\
\pm 0.01\end{array}$ \\
\hline $\mathrm{Mn}$ & $\begin{array}{l}688.0 \\
\pm 15.0\end{array}$ & $\begin{array}{l}722.8 \\
\pm 17.9\end{array}$ & $\begin{array}{l}510.0 \\
\pm 25.0\end{array}$ & $\begin{array}{l}475.6 \\
\pm 16.5\end{array}$ & $\mathrm{Hg}$ & $\begin{array}{c}0.089 \\
\pm 0.004\end{array}$ & $\begin{array}{c}0.08 \\
\pm 0.012\end{array}$ & $\begin{array}{c}0.015 \\
\pm 0.004\end{array}$ & $\begin{array}{c}0.02 \\
\pm 0.003\end{array}$ \\
\hline
\end{tabular}

The standard reference material NIM GBW 07428 that was included in the calibration was used as an unknown sample for the first check, while the second check was carried out by measuring the NIM GBW 07402 which was not included in the calibration and could represent a real unknown sample. Sediment samples for ED-XRF analyses were prepared as follows: after oven drying $\left(105^{\circ} \mathrm{C}\right)$ for $24 \mathrm{~h}$, grinding, homogenizing, and sieving, the pellets $(d=30 \mathrm{~mm})$ were made by pressing $4 \mathrm{~g}$ of material into a mold of the desired shape under high pressure. No binder material was applied. The residual ("dark") matrix was measured in sediment samples as a loss-on-ignition 
(L.O.I) upon heating in a muffle furnace at $500{ }^{\circ} \mathrm{C}$ for $4 \mathrm{~h}$. Organic matter in sediment samples was between $6.8 \%$ and $8.6 \%$. The L.O.I. parameters were used for calculation of the element concentrations in the sediment samples.

The minimum detection limits (MDL) for an analysis time of $100-500 \mathrm{~s}$ were: $100 \mathrm{mg} \mathrm{kg}^{-1}$ for $\mathrm{Si}, 50 \mathrm{mg} \mathrm{kg}^{-1}$ for $\mathrm{P}, \mathrm{Ca}$ and $\mathrm{K}, 20 \mathrm{mg} \mathrm{kg}^{-1}$ for $\mathrm{Sr}$ and $\mathrm{Ba}, 10 \mathrm{mg} \mathrm{kg}^{-1}$ for Ti and $\mathrm{Cr}, 8.0 \mathrm{mg} \mathrm{kg}^{-1}$ for $\mathrm{Mn}$ and $\mathrm{Fe}, 5.0 \mathrm{mg} \mathrm{kg}^{-1}$ for As and less than 2.0 $\mathrm{mg} \mathrm{kg}^{-1}$ for all the other elements. The MDLs were calculated from the standard sediment samples.

The degree of contamination in the sediments of the Boka Kotorska Bay for the investigated elements has been evaluated using the enrichment factor $(E F)$, pollution load index $(P L I)$ and geo-accumulation index $\left(I_{g e o}\right)$. The concentration of each element in the samples was compared with the reference to the baseline metal levels, the world shale value [14].

EF analysis, a method proposed by Simex and Helz (1981) [15] to assess trace element concentration, is mathematically expressed as:

$$
E F=\left(c_{\mathrm{x}} / \mathrm{Fe}\right)_{\text {sample }} /\left(c_{\mathrm{x}} / \mathrm{Fe}\right)_{\text {background }},
$$

where $c_{\mathrm{x}}$ stands for the concentration of metal "x". Average shale values [14] are commonly used to provide elemental background concentrations [8, 11], Table 3. The $E F$ is generally defined as the observed metal to $\mathrm{Al}$ ratio in the sample divided by the background metal/Al ratio. Commonly, geochemical normalization of the metals data to a conservative element, such as $\mathrm{Al}$ or $\mathrm{Fe}$, is employed in order to identify anomalous metal concentrations [16]. Al concentrations in the samples were not measured in this study. $\mathrm{Fe}$ is mainly from natural weathering processes and has been broadly used to normalize the metal concentrations in sediments [16]. Several authors have successfully used Fe to normalize heavy metals contaminants in sediment $[7,16]$.

The PLI, for a particular site, has been evaluated following the method proposed by Tomlinson et al. (1980) [17]. This parameter is expressed as:

$$
P L I=\left(C F_{1} \times C F_{2} \times C F_{3} \times \ldots \ldots \ldots \times C F_{n}\right)^{1 / n},
$$

where $n$ is the number of metals (20 in the present study) and $C F$ is the Contamination Factor. The Contamination Factor can be calculated from the following relation:

$$
C F=c_{\text {metal }} / c_{\text {Background value }} \text {. }
$$

The $I_{g e o}$, introduced by Müller (1979) [18] was also used beside $E F$ to assess metal pollution in sediments. It includes various degrees of enrichment above the background metal value ranging from unpolluted to much polluted sediment quality. The highest grade (class six) reflects 100fold enrichment above the background value [19]. To determine the extent of metal accumulation in sediments, $I_{g e o}$ has been used by various researchers in their studies $[8,20] . I_{g e o}$ is mathematically expressed as:

$$
I_{\text {geo }}=\log _{2}\left[c_{n} / 1.5 \mathrm{~B}_{n}\right],
$$

where $c_{n}$ is the concentration of an element " $n$ " and $\mathrm{B}_{n}$ is the geochemical background value of an element " $n$ ", the world shale average given by Turekian and Wedepohl, (1961) [14]. The factor 1.5 is incorporated into the relationship to account for possible variations in background data due to lithogenic effect.

\section{RESULTS AND DISCUSSION}

The average concentrations of the elements measured ( $\mathrm{Si}, \mathrm{Ca}, \mathrm{Fe}, \mathrm{K}, \mathrm{Ti}, \mathrm{Mn}, \mathrm{P}, \mathrm{Ba}, \mathrm{Sr}, \mathrm{Cr}, \mathrm{Zn}$, $\mathrm{Rb}, \mathrm{Ni}, \mathrm{Cu}, \mathrm{Pb}, \mathrm{As}, \mathrm{Sn}, \mathrm{Sb}, \mathrm{Hg}$, and $\mathrm{Cd}$ ) in the sediments of the Boka Kotorska Bay are summarized in Table 3. Data are in $\mathrm{mg} \mathrm{kg}^{-1}$ dry weight and with regard to the first $10 \mathrm{~cm}$ of surface sediments.

ED-XRF results for the collected sediment samples recorded the existence of the following major and minor elements: $\mathrm{Si}, \mathrm{Ca}, \mathrm{Fe}, \mathrm{K}, \mathrm{Ti}$ (major) and $\mathrm{P}, \mathrm{Mn}, \mathrm{Sr}, \mathrm{Cr}, \mathrm{Zn}, \mathrm{Cu}, \mathrm{Ni}, \mathrm{Pb}, \mathrm{Rb}, \mathrm{Ba}, \mathrm{As}$, $\mathrm{Sn}, \mathrm{Sb}, \mathrm{Hg}$ and $\mathrm{Cd}$ (minor). It is important to mention that $\mathrm{Cd}$ was determined only at the Orahovac location $\left(1 \mathrm{mg} \mathrm{kg}^{-1}\right), \mathrm{Hg}$ at four locations, and $\mathrm{Sb}$ at all locations, but in low quantities $\left(1-2 \mathrm{mg} \mathrm{kg}^{-1}\right)$. $\mathrm{Hg}$ at one location was determined in concentrations of $17 \mathrm{mg} \mathrm{kg}^{-1}$. For $\mathrm{Cd}, \mathrm{Hg}$, and $\mathrm{Sb}$ the ED-XRF results have not been analyzed because their concentrations were below or close to the detection limits of $2.0 \mathrm{mg} \mathrm{kg}^{-1}$, with the exception of $\mathrm{Hg}$ in the sample of Tivat-Arsenal site; $17.0 \mathrm{mg}$ $\mathrm{kg}^{-1}$. The mean concentrations of $\mathrm{K}, \mathrm{Ti}, \mathrm{Mn}$ and $\mathrm{Ba}$ in the surface sediment at all the locations were lower than their background values [14]. Concentrations of $\mathrm{Si}$ and $\mathrm{Ca}$ were higher than the background values for these elements at all locations, except $\mathrm{Ca}$ at location Bijela Port $\left(18833 \mathrm{mg} \mathrm{kg}^{-1}\right)$.

The highest average concentrations of heavy metals, such as $\mathrm{Cu}, \mathrm{Pb}, \mathrm{As}, \mathrm{Hg}$ and $\mathrm{Sn}$, were in the surface sediment at the Tivat-Arsenal site, in the small Tivat Bay; the highest average concen- 
trations of $\mathrm{Mn}, \mathrm{Pb}$ and $\mathrm{Zn}$, were in surface sediments at the Kotor site in the small Kotor Bay (Table 3). The obtained concentration for As presents a relatively homogeneous distribution along the Boka Kotorska Bay, from 11 to $19 \mathrm{mg} \mathrm{kg}^{-1}$. High contamination of As was found at the TivatArsenal location, $76 \mathrm{mg} \mathrm{kg}^{-1}$. $\mathrm{Hg}$ is a highly toxic element and its high concentration needs to be investigated to assess its possible sources and pathways in the small Tivat Bay.

Table 3

Concentrations of investigated elements in the sediments from different locations in the Boka Kotorska Bay, $\mathrm{mg} \mathrm{kg}^{-1}$

\begin{tabular}{|c|c|c|c|c|c|c|c|c|c|c|}
\hline & Krtole & $\begin{array}{c}\text { Tivat- } \\
\text { Airport }\end{array}$ & $\begin{array}{c}\text { Tivat- } \\
\text { Arsenal } \\
\end{array}$ & Kotor & Orahovac & Risan & Morinj & Bijela Port & $\begin{array}{c}\text { Herceg } \\
\text { Novi }\end{array}$ & Background* \\
\hline $\mathrm{Si}$ & 197273 & 216659 & 179770 & 162156 & 75725 & 181321 & 169135 & 244022 & 184976 & 73000 \\
\hline $\mathrm{Ca}$ & 30188 & 28784 & 102815 & 154941 & 246737 & 78170 & 34926 & 18833 & 73877 & 22100 \\
\hline $\mathrm{Sr}$ & 146 & 135 & 724 & 369 & 1423 & 234 & 176 & 85 & 202 & 300 \\
\hline $\mathrm{Ba}$ & 235 & 205 & 265 & 203 & 76 & 201 & 226 & 166 & 221 & 580 \\
\hline $\mathrm{K}$ & 23241 & 22859 & 12816 & 12622 & 6400 & 15139 & 19759 & 17735 & 16714 & 26600 \\
\hline $\mathrm{P}$ & 525 & 533 & 623 & 1371 & 673 & 768 & 579 & 465 & 484 & 700 \\
\hline $\mathrm{Fe}$ & 50780 & 45000 & 32982 & 28481 & 12090 & 30827 & 42829 & 27950 & 35334 & 47200 \\
\hline $\mathrm{Ti}$ & 4137 & 4037 & 2645 & 2647 & 1300 & 3430 & 3645 & 2668 & 3442 & 4600 \\
\hline $\mathrm{Rb}$ & 149 & 139 & 60 & 67 & 34 & 84 & 126 & 79 & 92 & 140 \\
\hline $\mathrm{Mn}$ & 591 & 507 & 565 & 805 & 415 & 505 & 782 & 488 & 591 & 850 \\
\hline $\mathrm{Cr}$ & 231 & 204 & 161 & 148 & 89 & 282 & 154 & 99 & 293 & 90 \\
\hline $\mathrm{Ni}$ & 202 & 157 & 82 & 106 & 37 & 104 & 146 & 69 & 165 & 68 \\
\hline $\mathrm{Zn}$ & 118 & 117 & 212 & 240 & 52 & 118 & 136 & 97 & 90 & 95 \\
\hline $\mathrm{Cu}$ & 47 & 42 & 82 & 44 & 14 & 34 & 52 & 60 & 38 & 45 \\
\hline $\mathrm{Pb}$ & 28 & 34 & 138 & 108 & 20 & 43 & 41 & 32 & 19 & 19 \\
\hline As & 19 & 18 & 76 & 14 & 13 & 15 & 18 & 17 & 11 & 13 \\
\hline $\mathrm{Sn}$ & 3.0 & 3.0 & 7.0 & 6.0 & 2.0 & 5.0 & 4.0 & 4.0 & 2.0 & 6 \\
\hline $\mathrm{Sb}$ & 1.0 & 1.0 & 1.0 & 1.0 & 1.0 & 2.0 & 2.0 & 2.0 & 1.0 & 1.5 \\
\hline $\mathrm{Cd}$ & n.d & n.d & n.d & n.d & 1.0 & n.d & n.d & n.d & n.d. & 0.3 \\
\hline $\mathrm{Hg}$ & n.d & n.d & 17 & 1.0 & n.d & 1.0 & n.d & n.d & n.d. & 1.4 \\
\hline
\end{tabular}

*Metal background values from Turekian and Wedepohl (1961): for average shale

The spatial distribution from element to element considerably changes in the small Kotor Bay, the sites Kotor and Orahovac, related to $\mathrm{Si}$, $\mathrm{Sr}, \mathrm{Ba}, \mathrm{K}, \mathrm{P}, \mathrm{Fe}, \mathrm{Ti}, \mathrm{Rb}, \mathrm{Cr}, \mathrm{Ni}, \mathrm{Zn}, \mathrm{Cu}$ and $\mathrm{Pb}$. At the Orahovac location, almost all obtained concentrations of the investigated elements were close to or lower than their background levels. Only $\mathrm{Ca}$ and $\mathrm{Sr}$ concentrations were much higher than their background values compared to the remaining elements. Metal deposits are in accordance with geo-hydrographic and population conditions in the small Kotor Bay. This bay has calm water, without currents and generally exchanges little water with the other parts of the Boka Kotorska Bay, espe- cially at the Kotor. The Kotor and Orahovac sites are characterized by karstic rivers and underground springs [1] and different human impacts: Kotor is a port, and a touristic and industrial city and Orahovac is a village with 300 residents, close to the very clean karstic Ljuta River which supplies the Kotor residents with drinking water.

Concentrations of heavy metals, such as $\mathrm{Cr}$, $\mathrm{As}, \mathrm{Cu}, \mathrm{Zn}, \mathrm{Pb}, \mathrm{Cd}$ and $\mathrm{Hg}$, at the Tivat-Arsenal location, were evaluated in the surface sediment from the Bay in terms of ecological risk to marine organisms by comparing them to the numerical $S Q G$ s proposed by USEPA [13], Table 4. Based on the $S Q G$ s proposed by USEPA, the sediments were 
categorized into three classes, non-polluted, moderately polluted and heavily polluted, by comparing the mean concentrations of the heavy metals mentioned above. Based on this comparison, surface sediments in the entire Boka Kotorska Bay can be classified as heavily polluted by As and $\mathrm{Cr}$, and non-polluted by $\mathrm{Cd}$ and $\mathrm{Hg}$. Based on USEPA's SQGs [13], the surface sediment at the Tivat-Arsenal site was heavily polluted by $\mathrm{Cr}$, As, $\mathrm{Cu}, \mathrm{Zn}, \mathrm{Pb}$, and $\mathrm{Hg}$, and non-polluted at Orahovac. These guidelines may not be validated for use in the Bay because there may be fundamental differences in sediment geochemistry [10].

Table 4

Surface sediment classifications by USEPA's SQGs based on element concentrations, $\mathrm{mg} \mathrm{kg}^{-1}$

\begin{tabular}{cccc}
\hline \hline Elements & $\begin{array}{c}\text { Non- } \\
\text { polluted }\end{array}$ & $\begin{array}{c}\text { Moderately } \\
\text { polluted }\end{array}$ & $\begin{array}{c}\text { Heavily } \\
\text { polluted }\end{array}$ \\
\hline $\mathrm{As}$ & $<3$ & $3-8$ & $>8$ \\
$\mathrm{Cd}$ & - & - & $>6$ \\
$\mathrm{Cr}$ & $<25$ & $25-75$ & $>75$ \\
$\mathrm{Cu}$ & $<25$ & $25-50$ & $>50$ \\
$\mathrm{Ni}$ & $<20$ & $20-50$ & $>50$ \\
$\mathrm{~Pb}$ & $<40$ & $40-60$ & $>60$ \\
$\mathrm{Zn}$ & $<90$ & $90-200$ & $>200$ \\
\hline \hline
\end{tabular}

$C F$ is the ratio between the concentration of heavy metals in the study area and the background level [14]. This index is used in order to compare the pollution status of different places and it varies from 0 (unpolluted) to 10 (highly polluted). The ranges used to describe the contamination factor are: $C F<1$ is considered as low contamination; 1 $<C F<3$ is moderate contamination; $3<C F<6$ is considerable contamination and $C F>6$ is high contamination [11]. The highest obtained $C F$ s for the investigated elements in the surface sediment at some locations in the Boka Kotorska Bay related to the world shale values were found in the following order (Table 5):

$$
\mathrm{Ca}>\mathrm{Pb}>\mathrm{As}>\mathrm{Si}>\mathrm{Cr}>\mathrm{Sr}>\mathrm{Ni}>\mathrm{Zn}>\mathrm{Sn}
$$

Concentration levels of $\mathrm{Si}, \mathrm{Ca}, \mathrm{Cr}, \mathrm{Ni}, \mathrm{Zn}$, $\mathrm{As}$, and $\mathrm{Pb}$ in most of the stations exceeded the world average concentration of shale and was reflected in $C F$ values $>1$, Table $5 . C F<1$ is considered as low contamination and was found in the case of $\mathrm{K}, \mathrm{Ti}, \mathrm{Mn}, \mathrm{Rb}, \mathrm{Ba}, \mathrm{Fe}$ and $\mathrm{Sn}$, mostly at all the locations. $\mathrm{Pb}$ concentration was high in the study area and the $C F$ value for $\mathrm{Pb}$ ranged from 1.0 to 7.3, suggesting low (Herceg Novi and Orahovac) to high contamination (Kotor and TivatArsenal) of surface sediments in the bay.

Table 5

Contamination factors $(C F)$ and pollution load index (PLI) for surface sediments at locations in the Boka Kotorska Bay

\begin{tabular}{|c|c|c|c|c|c|c|c|c|c|}
\hline Elements & Krtole & $\begin{array}{l}\text { Tivat- } \\
\text { Airport }\end{array}$ & $\begin{array}{l}\text { Tivat- } \\
\text { Arsenal }\end{array}$ & Kotor & Orahovac & Risan & Morinj & $\begin{array}{c}\text { Bijela } \\
\text { Port }\end{array}$ & $\begin{array}{c}\text { Herceg } \\
\text { Novi }\end{array}$ \\
\hline $\mathrm{Si}$ & 2.7 & 3.0 & 2.5 & 2.2 & 1.0 & 2.5 & 2.3 & 3.3 & 2.5 \\
\hline $\mathrm{Cr}$ & 2.6 & 2.3 & 1.8 & 1.6 & 0.99 & 3.1 & 1.7 & 1.1 & 3.3 \\
\hline $\mathrm{Ca}$ & 1.4 & 1.3 & 4.6 & 7.0 & 11.2 & 3.5 & 1.6 & 0.85 & 3.3 \\
\hline $\mathrm{Sr}$ & 0.49 & 0.45 & 2.4 & 1.2 & 4.7 & 0.78 & 0.59 & 0.28 & 0.67 \\
\hline $\mathrm{Ba}$ & 0.40 & 0.35 & 0.46 & 0.35 & 0.13 & 0.35 & 0.39 & 0.30 & 0.38 \\
\hline $\mathrm{P}$ & 0.75 & 0.76 & 0.89 & 1.9 & 0.96 & 1.1 & 0.83 & 0.66 & 0.69 \\
\hline $\mathrm{K}$ & 0.87 & 0.86 & 0.48 & 0.5 & 0.24 & 0.60 & 0.74 & 0.67 & 0.63 \\
\hline $\mathrm{Ti}$ & 0.90 & 0.89 & 0.58 & 0.6 & 0.3 & 0.75 & 0.79 & 0.58 & 0.75 \\
\hline $\mathrm{Mn}$ & 0.70 & 0.59 & 0.66 & 0.95 & 0.5 & 0.59 & 0.92 & 0.57 & 0.66 \\
\hline $\mathrm{Fe}$ & 1.1 & 0.95 & 0.70 & 0.60 & 0.3 & 0.65 & 0.9 & 0.59 & 0.75 \\
\hline $\mathrm{Ni}$ & 3.0 & 2.3 & 1.2 & 1.6 & 0.54 & 1.5 & 2.2 & 1.0 & 2.4 \\
\hline $\mathrm{Cu}$ & 1.0 & 0.9 & 1.8 & 0.98 & 0.3 & 0.76 & 1.2 & 1.3 & 0.8 \\
\hline $\mathrm{Zn}$ & 1.2 & 1.2 & 2.2 & 2.5 & 0.55 & 1.2 & 1.4 & 1.0 & 0.95 \\
\hline As & 1.5 & 1.4 & 5.9 & 1.1 & 1.0 & 1.2 & 1.4 & 1.3 & 0.85 \\
\hline $\mathrm{Rb}$ & 1.1 & 0.99 & 0.43 & 0.48 & 0.24 & 0.6 & 0.9 & 0.56 & 0.66 \\
\hline $\mathrm{Sn}$ & 0.5 & 0.5 & 1.2 & 1.0 & 0.33 & 0.83 & 0.67 & 0.67 & 0.33 \\
\hline $\mathrm{Hg}$ & - & - & 12.1 & 0.47 & - & - & - & - & - \\
\hline $\mathrm{Pb}$ & 1.5 & 1.8 & 7.3 & 5.7 & 1.0 & 2.3 & 2.2 & 1.7 & 1.0 \\
\hline$P L I_{\text {shale }}$ & 1.08 & 1.02 & 1.6 & 1.2 & 0.64 & 1.06 & 1.08 & 0.80 & 0.94 \\
\hline
\end{tabular}


The surface sediment at the Tivat-Arsenal location was highly contaminated with $\mathrm{Hg}$ (12.1) and $\mathrm{Pb}$ (7.3), and considerably contaminated with As (5.9) and $\mathrm{Ca}$ (4.6), according to the $C F$ value [17]. Also, the surface sediment from the Kotor site was highly contaminated with $\mathrm{Ca}(7.0)$ and $\mathrm{Pb}$ (5.7). The surface sediment at the Orahovac location was highly contaminated with $\mathrm{Ca}$ (11.2) and considerably contaminated with $\mathrm{Sr}$ (4.7). Considerable contamination was also observed at the $\mathrm{Bi}$ jela ( $\mathrm{Si})$, Risan $(\mathrm{Ca}$ and $\mathrm{Cr}$ ) and Herceg Novi $(\mathrm{Ca}$ and $\mathrm{Cr}$ ) locations, Table 5. High $C F$ values for $\mathrm{Si}$ and $\mathrm{Ca}$ at all the locations can be explained by rainfall and bottom springs naturally leached, and from dead marine organisms, especially at the Orahovac location.

The PLI represents the number of times by which the heavy metal concentrations in the sediment exceeds the background concentration, and gives a summative indication of the overall level of heavy metal toxicity in a particular sample [21]. Generally, the $P L I$ is a convenient measure of geochemical trends and is used for comparison among areas. The $P L I$ value of $>1$ is polluted, whereas $<1$ indicates no pollution [22]. The $P L I$ calculated for different sites (Table 5) were found to be the highest in the surface sediment at Tivat-Arsenal (1.6) then at Kotor (1.2). Sediments in Morinj, Risan, Krtole and Tivat-Airport had approximately the same PLI (1.0), Herceg Novi (0.94), Bijela Port $(0.80)$ and the lowest was in Orahovac (0.64). Low values of $P L I$ in these locations implied no appreciable input from anthropogenic sources. There is, in general, a decrease in $P L I$ values in the small Tivat Bay (Tivat-Arsenal $>$ Tivat-Airport $>$ Bijela Port) indicating dilution and dispersion of metal content in surface sediments with increasing distance from anthropogenic sources such as: Tivat city, Tivat marina, the shipyard, the military harbor and agricultural activity in the background of Tivat Bay.

$E F$ is a convenient measure of the trends of geochemical elements and it is used to assess the anthropogenic and lithogenic metal contribution into a site and for comparison among areas. To determine the anthropogenic and/or natural impact on the concentration of investigated elements in the sediment samples, that is, to ascertain whether there was enrichment of analyzed elements relative to the background level, the $E F$ was calculated and is shown in Table 6 . When the $E F$ value is in the range of $0.5 \leq E F \leq 1.5$, it suggests that the metals may be entirely as a result of crustal materials or natural weathering processes [23], but when $E F>$ 1.5 it suggests that a significant portion of trace metals are provided by other sources [23, 24]. Some other $E F$ categories are recognized: < 1 background concentration, 1-2 depletion to minimal enrichment, 2-5 moderate enrichment, 5-20 significant enrichment, 20-40 very high enrichment and > 40 extremely high enrichment [25]; alternatively, $E F$ values ranging between 0.5 and 2 can be considered in the range of natural variability, whereas ratios between 2 and 10 indicate some enrichment caused by the presence of humans, and a clear indication of substantially increased values caused by human influence (anthropogenic inputs) is where $E F \geq 10$ [26].

The $E F$ values for $\mathrm{Si}, \mathrm{Ca}, \mathrm{Cr}, \mathrm{Ni}, \mathrm{Zn}$, As, and $\mathrm{Pb}$ were higher than one for all investigated sediment samples. The highest $E F$ values for $\mathrm{Hg}$ (17.4), $\mathrm{Pb}$ (10.4), and As (8.4) at the Tivat-Arsenal location, Table 6 , indicate the anthropogenic enrichment sources of these elements. The $E F$ of $\mathrm{Si}$ was fairly high $(\sim 3)$ and had similar values at all the investigated locations. Almost uniformly high $E F$ values for $\mathrm{Si}$ along the entire Boka Kotorska Bay negate the presence of local enrichment factors for $\mathrm{Si}$, and it can be concluded that $\mathrm{Si}$ was mainly of natural origin. The same conclusion can be derived for $\mathrm{Cr}$ also, since this metal is associated with silicate minerals [25]. On the other hand, $E F$ values for $\mathrm{Rb}, \mathrm{Ba}, \mathrm{K}$ and $\mathrm{Ti}$ at all locations show background concentration: $E F$ was $\leq 1$. $\mathrm{K}$ and $\mathrm{Rb}$ are alkali metals and have similar chemical properties and occur mostly as lithophiles according to Goldschmidt's classification of geochemical elements [27]. The EFs of $\mathrm{Pb}$ and $\mathrm{As}$ were also fairly high and different from site to site, acknowledging their anthropogenic sources.

The sediment from Tivat-Arsenal was significantly enriched with $\mathrm{Hg}, \mathrm{Pb}$, and As, indicating high anthropogenic contamination at this location. Also, locations with significantly enriched surface sediments with some investigated elements were: Kotor with $\mathrm{Ca}$ and $\mathrm{Pb}$, Orahovac with $\mathrm{Ca}$ and $\mathrm{Sr}$, Risan with $\mathrm{Ca}$ and Bijela Port with $\mathrm{Si}$.

The sediment sample from the Orahovac location had extremely high enrichment with $\mathrm{Ca}$ (43.6) and significant enrichment with $\mathrm{Sr}$ (18.5), indicating their lithogenic source and the remains of dead marine organisms, that is, impacted by the hydrology of this part of the bay where there is almost no movement of seawater. Also, $\mathrm{Ca}$ in the form of calcite, aragonite or bio-aragonite (several marine organisms such as mollusks, bivalves, corals, etc., secrete biogenic aragonite or calcite) is followed by $\mathrm{Sr}$ [28], since they have similar chemical properties [25]. 
T a ble 6

Enrichment factors (EFs) for Boka Kotorska Bay sediments normalized with respect to the iron content and the background iron value

\begin{tabular}{cccccccccc}
\hline \hline Locations & Krtole & $\begin{array}{c}\text { Tivat- } \\
\text { Airport }\end{array}$ & $\begin{array}{c}\text { Tivat- } \\
\text { Arsenal }\end{array}$ & Kotor & Orahovac & Risan & Morinj & $\begin{array}{c}\text { Bijela } \\
\text { Port }\end{array}$ & $\begin{array}{c}\text { Herceg } \\
\text { Novi }\end{array}$ \\
\hline $\mathrm{Si}$ & 2.5 & 3.1 & 3.5 & 3.7 & 4.0 & 3.8 & 2.6 & 5.6 & 3.4 \\
$\mathrm{Cr}$ & 2.4 & 2.4 & 2.6 & 2.7 & 3.9 & 4.8 & 1.9 & 1.9 & 4.3 \\
$\mathrm{Ca}$ & 1.3 & 1.4 & 6.7 & 11.6 & 43.6 & 5.4 & 1.7 & 1.4 & 4.5 \\
$\mathrm{Sr}$ & 0.45 & 0.47 & 3.4 & 2.0 & 18.5 & 1.2 & 0.65 & 0.48 & 0.90 \\
$\mathrm{Ba}$ & 0.38 & 0.37 & 0.65 & 0.58 & 0.51 & 0.53 & 0.43 & 0.48 & 0.51 \\
$\mathrm{P}$ & 0.70 & 0.80 & 1.3 & 3.2 & 3.7 & 1.7 & 0.91 & 1.1 & 0.92 \\
$\mathrm{~K}$ & 0.81 & 0.90 & 0.69 & 0.79 & 0.94 & 0.87 & 0.82 & 1.1 & 0.84 \\
$\mathrm{Rb}$ & 0.99 & 1.0 & 0.61 & 0.79 & 0.95 & 0.92 & 0.99 & 0.95 & 0.88 \\
$\mathrm{Fe}$ & 1.0 & 1.0 & 1.0 & 1.0 & 1.0 & 1.0 & 1.00 & 1.0 & 1.0 \\
$\mathrm{Ti}$ & 0.84 & 0.92 & 0.82 & 0.95 & 1.1 & 1.1 & 0.87 & 0.98 & 1.0 \\
$\mathrm{Mn}$ & 0.65 & 0.63 & 0.95 & 1.6 & 1.9 & 0.91 & 1.0 & 0.97 & 0.93 \\
$\mathrm{Ni}$ & 2.8 & 2.4 & 1.7 & 2.6 & 2.1 & 2.3 & 2.4 & 1.7 & 3.2 \\
$\mathrm{Cu}$ & 0.97 & 0.98 & 2.6 & 1.6 & 1.2 & 1.2 & 1.3 & 2.3 & 1.1 \\
$\mathrm{Zn}$ & 1.2 & 1.3 & 3.2 & 4.2 & 2.1 & 1.9 & 1.6 & 1.7 & 1.3 \\
$\mathrm{As}$ & 1.4 & 1.4 & 8.4 & 1.8 & 3.9 & 1.8 & 1.5 & 2.2 & 1.1 \\
$\mathrm{Sn}$ & 0.46 & 0.52 & 1.7 & 1.7 & 1.3 & 1.3 & 0.73 & 1.1 & 0.45 \\
$\mathrm{Hg}$ & $/$ & $/$ & 17.4 & $/$ & $/$ & $/$ & $/$ & $/$ & $/$ \\
$\mathrm{Pb}$ & 1.4 & 1.9 & 10.4 & 9.4 & 4.1 & 3.5 & 2.4 & 2.8 & 1.3 \\
\hline \hline
\end{tabular}

The high $E F$ values of $\mathrm{Cr}$ (Risan $>$ Herceg Novi $>$ Orahovac), Ni (Herceg Novi $>$ Krtole $>$ Kotor), and Zn (Kotor > Tivat-Arsenal) found in sediments collected could be from anthropogenic sources, but can be explained by taking into account the geological composition of the hydrographic basins of the southeastern Adriatic [4, 6]. The enrichment of $\mathrm{Ni}$ and other elements specific to basic eruptive rocks is found everywhere in the Dinaric chain area [4]. Albania is known as the first country with $\mathrm{Cr}$ and the third with $\mathrm{Ni}$ resources in the world [4]. Relatively high levels of $\mathrm{Cr}$ and $\mathrm{Ni}$ were found in estuarine sediment samples in front of the river mouths in Albania [7, 8], but no higher than in Boka Kotorska Bay, suggesting similar geology at this coastal area of the southeastern Adriatic [6].

The higher enrichment of $\mathrm{Cr}$ in the Risan and Orahovac sediment samples, Table 6, than in Tivat Bay and Kotor, which are more impacted by human activities, can be explained by natural impact: Risan Bay generally exchanges little water with the Adriatic Sea and it is characterized by karstic rivers, underground springs [1] and small residential populations (4000 residents). The fact is that the rivers entering the Boka Kotorska Bay are not severely impacted by man [1], confirming the hypothesis that the main origin of the high $\mathrm{Cr}$ content in the sampled area is due to the mineralogical composition of the bay, such as in the southeastern Adriatic coastal area $[4,6,8]$.

The $I_{\text {geo }}$ introduced by Müller (1979) [18] was also used, besides EF, for determining the extent of the metal accumulation in sediments. According to the scale established by Müller, a sediment can be classified as non-polluted $\left(I_{g e o}<1\right)$, very slightly polluted $\left(1<I_{\text {geo }}<2\right)$, slightly polluted $\left(2<I_{\text {geo }}<3\right)$, moderately polluted $\left(3<I_{\text {geo }}\right.$ $<4)$, highly polluted $\left(4<I_{g e o}<5\right)$, and very highly polluted $\left(I_{\text {geo }}>5\right)$. The $I_{\mathrm{geo}} \mathrm{S}$ for each element at each sampling site were calculated using background values [14], Table 3 . The calculated $I_{g e o}$ values, based on the world shale average, are presented in Table 7.

The results of the $I_{\text {geo }}$ (Table 7) indicate that the sampling sites Krtole, Tivat-Airport and Morinj are classified as non-polluted considering all the investigated elements. The Risan and Herceg Novi locations were very slightly polluted with $\mathrm{Ca}$ and $\mathrm{Cr}$, and the Bijela Port location with $\mathrm{Si}$. The sediment samples at Tivat-Arsenal $(\mathrm{Ca}, \mathrm{As}, \mathrm{Pb}$ and $\mathrm{Hg})$, Kotor $(\mathrm{Ca}, \mathrm{Pb})$ and Orahovac $(\mathrm{Ca}, \mathrm{Sr})$ had $I_{\text {geo }}$ values between 2 and 3, indicating slight pollution with these elements. 
T a ble 7

Geo-accumulation index $\left(I_{\text {geo }}\right)$ values calculated for each element in all sampling sites for the surface sediment in Boka Kotorska Bay

\begin{tabular}{cccccccccc}
\hline \hline Locations & Krtole & $\begin{array}{c}\text { Tivat- } \\
\text { Airport }\end{array}$ & $\begin{array}{c}\text { Tivat- } \\
\text { Arsenal }\end{array}$ & Kotor & Orahovac & Risan & Morinj & $\begin{array}{c}\text { Bijela } \\
\text { Port }\end{array}$ & $\begin{array}{c}\text { Herceg } \\
\text { Novi }\end{array}$ \\
\hline $\mathrm{Si}$ & 0.85 & 0.98 & 0.72 & 0.57 & -0.53 & 0.73 & 0.63 & 1.2 & 0.76 \\
$\mathrm{Cr}$ & 0.77 & 0.60 & 0.25 & 0.13 & -0.60 & 1.1 & 0.19 & -0.45 & 1.1 \\
$\mathrm{Ca}$ & -0.14 & -0.20 & 1.6 & 2.2 & 2.9 & 1.2 & 0.08 & -0.82 & 1.2 \\
$\mathrm{Sr}$ & -1.6 & -1.7 & 0.69 & -0.29 & 1.7 & -0.94 & -1.4 & -2.4 & -1.2 \\
$\mathrm{Ba}$ & -1.9 & -2.1 & -1.7 & -2.1 & -3.5 & -2.1 & -1.9 & -2.4 & -2.0 \\
$\mathrm{P}$ & -1.0 & -0.98 & -0.75 & 0.38 & -0.64 & -0.45 & -0.86 & -1.2 & -1.1 \\
$\mathrm{~K}$ & -0.78 & -0.80 & -1.6 & -1.7 & -2.6 & -1.4 & -1.0 & -1.2 & -1.3 \\
$\mathrm{Rb}$ & -0.50 & -0.60 & -1.8 & -1.6 & -2.6 & -1.3 & -0.74 & -1.4 & -1.2 \\
$\mathrm{Ti}$ & -0.74 & -0.77 & -1.4 & -1.4 & -2.4 & -1.0 & -0.92 & -1.4 & -1.0 \\
$\mathrm{Fe}$ & -0.48 & -0.65 & -1.1 & -1.3 & -2.5 & -1.2 & -0.73 & -1.3 & -1.0 \\
$\mathrm{Mn}$ & -1.1 & -1.3 & -1.2 & -0.66 & -1.6 & -1.3 & -0.71 & -1.4 & -1.1 \\
$\mathrm{Ni}$ & 0.99 & 0.62 & -0.31 & 0.06 & -1.5 & 0.03 & 0.52 & -0.56 & 0.69 \\
$\mathrm{Cu}$ & -0.52 & -0.68 & 0.28 & -0.62 & -2.3 & -0.99 & -0.38 & -0.17 & -0.83 \\
$\mathrm{Zn}$ & -0.27 & -0.28 & 0.57 & 0.75 & -1.4 & -0.27 & -0.07 & -0.55 & -0.66 \\
$\mathrm{As}$ & -0.04 & -0.12 & 2.0 & -0.48 & -0.58 & -0.38 & -0.12 & -0.20 & -0.83 \\
$\mathrm{Sn}$ & -1.6 & -1.6 & -0.36 & -0.58 & -2.2 & -0.85 & -1.2 & -1.2 & -2.2 \\
$\mathrm{Hg}$ & $/$ & $/$ & 3.0 & $/$ & $/$ & $/$ & $/$ & $/$ & $/$ \\
$\mathrm{Pb}$ & -0.03 & 0.25 & 2.3 & 1.9 & -0.51 & 0.59 & 0.52 & 0.17 & -0.58 \\
\hline \hline
\end{tabular}

Taking into account the considerations of various authors $[25,26]$ related to the different limited $E F$ values for the natural or anthropogenic nature of elements in surface sediments, and on the bases of $P L I$ and $I_{g e o}$ values, the compatibility of the used indexes of the investigated elements in this study is shown in Table 8. After all, it can be concluded that the surface sediments in the bay at the Tivat-Arsenal location were polluted by $\mathrm{Hg}, \mathrm{Pb}$ and $\mathrm{As}$, and at the Kotor site with $\mathrm{Pb}$. The contamination of the Tivat-Arsenal surface sediment by $\mathrm{Pb}, \mathrm{Hg}$ and $\mathrm{As}$ is widely due to marine, shipping, and agricultural activities in the Tivat Valley, from atmospheric sources, and domestic effluents. The high concentration of $\mathrm{Pb}$ in the Kotor surface sediment is due to marine and traffic activities, such as atmospheric fall-out of $\mathrm{Pb}$ [4].

Table 8

Compatibility of the indexes for elements in the bay sediments

\begin{tabular}{lccc}
\hline \hline Location & $C F$ & $E F$ & $I_{\text {geo }}$ \\
\hline Tivat-Arsenal & $\mathrm{Hg}, \mathrm{Pb}, \mathrm{As}, \mathrm{Ca}$ & $\mathrm{Hg}, \mathrm{Pb}, \mathrm{As}, \mathrm{Ca}$ & $\mathrm{Hg}, \mathrm{Pb}, \mathrm{As}, \mathrm{Ca}$ \\
Kotor & $\mathrm{Ca}, \mathrm{Pb}$ & $\mathrm{Ca}, \mathrm{Pb}$ & $\mathrm{Ca}, \mathrm{Pb}$ \\
Orahovac & $\mathrm{Ca}, \mathrm{Sr}$ & $\mathrm{Ca}, \mathrm{Sr}$ & $\mathrm{Ca}, \mathrm{Sr}$ \\
Risan & $\mathrm{Ca}, \mathrm{Cr}$ & $\mathrm{Ca}$ & $\mathrm{Ca}, \mathrm{Cr}$ \\
Bijela Port & $\mathrm{Si}$ & $\mathrm{Si}$ & $\mathrm{Si}$ \\
Herceg Novi & $\mathrm{Ca}, \mathrm{Cr}$ & $/$ & $\mathrm{Ca}, \mathrm{Cr}$ \\
\hline \hline
\end{tabular}

Surface sediments in Tivat-Arsenal and Bijela Port are very different from other stations $(\mathrm{Ta}-$ ble 8 ). The high concentrations of $\mathrm{Si}$ and $\mathrm{Ca}$, and their enrichment at these locations, can be explained by the Bay's geochemistry, and hydrology, and the importance of local hydrography [3]. The Boka Kotorska Bay is an area characterized by fresh water inputs [1], it is one of the rainiest parts in Europe and has the largest precipitation amount on the continent [3]. Rainfall from the high mountains surrounding the bay, especially in the fall, also the occurrence of numerous springs and karstic rivers around the bay, such as the bottom springs in the Kotor and Risan Bays [3], surely impact the chemistry of surface sediments in the Boka Kotorska Bay and the high natural occurrence of $\mathrm{Si}$ and $\mathrm{Ca}$ concentrations throughout the Bay bottom. This supports the hypothesis that the 
terrestrial inputs in the bay are rich in $\mathrm{Ca}$ and $\mathrm{Si}$. High concentrations of Si at the Bijela Port location were derived from mountain rocks weathering in the hinterland of Bijela Port.

Sources of $\mathrm{Sr}$ in the Orahovac surface sediment are mainly the remains of marine organisms which have accumulated and decomposed over time in the surface sediment, and at the same time the surface sediment is impacted by hydrology at this location: calm water without any mixing from other parts of the bay.

The hinterland of Kotor, Orahovac and Risan comprises carbonate rocks, that is, silificated limestone covered by flysch [3], which consists of repeated sedimentary cycles, evolved into sandstone or shale/claystone. The coarser sandstones often have mica fractions. Chemically, the general mica formula comprises $(\mathrm{Ca}, \mathrm{Na}, \mathrm{K})_{2}(\mathrm{Mg}, \mathrm{Fe}, \mathrm{Mn}$, $\mathrm{Cr}, \mathrm{Ti})_{6}(\mathrm{Si}, \mathrm{Al})_{8} \mathrm{O}_{20}(\mathrm{OH}, \mathrm{F})_{4}$. This may possibly explain the high level of Cr over the bay bottom [3].

\section{CONCLUSIONS}

This research can be used as the basic data for future assessment of some major, minor and trace elements in surface sediments in the Boka Kotorska Bay. The geology of the surrounding mountains of the bay, the impact of large amounts of rainfall during the fall and winter, karstic rivers and underground springs, and the specific bay hydrology play an important role in the level and distribution of the investigated elements in the surface sediment of the bay. Using the data presented, it is obvious that surface sediments in the Boka Kotorska Bay are enriched with $\mathrm{Si}, \mathrm{Ca}, \mathrm{Sr}$, and $\mathrm{Cr}$ originating from natural sources, and with $\mathrm{Hg}, \mathrm{Pb}$, and As from anthropogenic sources. To determine the true state of the surface sediments in the Boka Kotorska Bay and the southeastern Adriatic coast, it is necessary to determine the regional background of the analyzed elements.

Acknowledgment: This work was supported by project III 43009 of the Serbian Ministry of Science.

\section{REFERENCES}

[1] A. Campanelli, A. Bulatović, M. Cabrini, F. Grilli, Z Kljajić, R. Mosetti, R. Paschini, P. Penna, M. Marini, Spatial distribution of physical, chemical and biological oceanographic properties, phytoplankton, nutrients and colored dissolved organic matter (CDOM) in the Boka Kotorska Bay (Adriatic Sea). Geophys., 26, 215-228 (2009).

[2] M. Jović, A. Stanković Slavković, L. Beskoski, I Tomić, S. Degetto, S. Stanković. Mussels as a bio- indicator of the environmental quality of the coastal water of the Boka Kotorska Bay (Montenegro). J. Serb. Chem. Soc., 76, 933-946 (2011).

[3] D. Magas, Natural-geographic characteristics of the Boka Kotorska area as the basis of development. Geoadria., 7/1, 51-81 (2002).

[4] P. Rivaro, C. Ianni, S. Massolo, N. Ruggieri, R. Frache, Heavy metals in Albanian coastal sediments. Toxicol. Environ. Chem., 86, 85-97 (2004).

[5] J. Obhodas, V. Valković, Contamination of the coastal sea sediments by heavy metals. Appl. Radiat. Isot., 68, 807-811 (2010).

[6] T. Dolenc, J. Faganeli, S. Pirc, Major, minor and trace elements in surficial sediments from the open Adriatic Sea: A regional geochemical study. Geol. Croatica, 1, 59-73 (1998).

[7] V. Çelo, D. Babi, B. Baraj, A. Çullaj. An assessment of heavy metal pollution in the sediments along the Albanian Coast. Water Air Soil Pollut., 111, 235-250 (1999).

[8] P. Rivaro, A. Cullaj, R. Frache, C. Lagomarsino, S. Massolo, C. M. De Mattia, N. Ungaro, Heavy metals distribution in suspended particulate matter and sediment collected from Vlora Bay (Albania): A methodlogical approach for metal pollution evaluation. J. Coast. Res., 58, 54-66 (2011).

[9] D. Joksimović, I. Tomić, R. A. Stanković, M. Jović, S. Stanković, Trace metal concentrations in Mediterranean blue mussel and surface sediments and evaluation of the mussels' quality and possible risks of high human consumption. Food Chem., 127, 632-637 (2011).

[10] D. Joksimović, S. Stanković, Accumulation of trace metals in marine organisms of the southeastern Adriatic coast, Montenegro. J. Serb. Chem. Soc., 77, 105-117 (2012).

[11] H. Pekey, Heavy metals pollution assessment in sediments of the Izmir Bay, Turkey. Environ. Monit. Assess., 123, 219-231 (2006).

[12] S. Caeiro, M. H. Costa, T. B. Ramos, F. Fernandes, N. Silveira, A. Coimbra, G. Medeiros, M. Painho. Assessing heavy metal contamination in Sado Estuary sediment: An index analysis approach. Ecol. Indic., 5, 151169 (2005).

[13] P. J. Giesy, R. A. Hoke, Freshwater sediment quality criteria: Toxicity bioassessment in sediment: Chemistry and toxicity of in-place pollutants, Lewis Publishers, Ann Arbor, Boston, (1990).

[14] K. K. Turekian, K. H. Wedepohl, Distribution of elements in some major units of the Earth's crust. Geol. Soc. Am. Bull., 72, 175-192 (1961).

[15] S. A. Simex, G. R. Helz, Regional geochemistry of trace elements in Chesapeake Bay. Environ. Geol., 3, 315323 (1981).

[16] E. Esen, F. Kucuksezgin, E. Uluturhan, Assessment of trace metal pollution in surface sediments of Nemrut Bay, Aegean Sea. Environ. Monit. Assess., 160, 257-266 (2010).

[17 D. L. Tomlinson, J. G. Wilson, C. R. Harris, D. W. Jeffrey, Problems in the assessment of heavy-metal levels 
in estuaries and the formation of a pollution index. $\mathrm{Hel}$ gol. Mar. Res., 33, 566-575 (1980).

[18] G. Müller. Schwermetalle in den Sediment des Rheins. Veranderungen Seit,79, 778-783 (1979).

[19] A. K. Singh, S. I. Hasnain, D. K. Banerjee, Grain size and geochemical portioning of heavy metals in sediments of the Damodar River - A tributary of the Lower Ganga. Environ. Geol., 39, 90-98 (2003).

[20] B. Tavakoly Sany, A. Salleh, A. H .Sulaiman, A. Mehdinia, G. H. Monazami, Geochemical assessment of heavy metals concentration in surface sediment of West Port, Malaysia. Eng. Techn., 80, 83-87 (2011).

[21] C. P. Priju, A. C. Narayana, Spatial and temporal variability of trace element concentrations in a tropical lagoon, Southwest Coast of India: Environmental Implications. J. Coast. Res., 39, 1053-1057 (2006).

[22] P. S. Harikumar, U. P. Nasir, M. P. Mujeebu Rahma, Distribution of heavy metals in the core sediments of a tropical wetland system. Int. J. Environ. Sci. Technol., 6, 225-232 (2009).
[23] L. Zhang, X. Ye, H. Feng, Y. Jing, T. Ouyang, X. Yu, Heavy metal contamination in western Xiamen Bay sediments and its vicinity, China. Mar. Poll. Bull., 54, 974-982 (2007).

[24] P. S. Harikumar, T. S. Jisha, Distribution pattern of trace metal pollutants in the sediments of an urban wetland in the southwest coast of India. JESTECH, 2, 840-850 (2010).

[25] P. K. E. Bam, T. T. Akiti, D. S. Osea, Y. S. Ganyaglo, A. Gibrilla, Multivariate cluster analysis of some major and trace elements distribution in an unsaturated zone profile, Densu River Basin, Ghana. Afr. J. Environ. Sci. Technol., 3, 155-167 (2011).

[26] L. Hernandez, A. Probst, J. L. Probst, E. Ulrich, Heavy metal distribution in some French forest soils: Evidence for atmosphere contamination. Sci. Total Environ., 312, 195-210 (2003).

[27] B. Mason, C. Moore, Principles of geochemistry. John Wiley \& Sons, New York, USA, (1982).

[28] M. S. Antao, The crystal structure of a biogenic aragonite from the nacre of an ammonite shell. RSC Adv., 2, 526-530 (2012). 